\title{
Between Political Meritocracy and Participatory Democracy: Toward Realist Confucian Democracy
}

\author{
Darren Yutang Jin \\ Hertford College, Department of Politics and International Relations, \\ University of Oxford, Oxford, UK \\ yutang.jin@hertford.ox.ac.uk
}

\begin{abstract}
In this article, I examine the textual underpinnings of participatory Confucian democracy and Confucian meritocracy and propose realist Confucian democracy as an alternative following a balanced reading of classic Confucianism. I argue that Confucian plebeian values do not square with the political meritocrats' (Daniel A. Bell and Tongdong Bai) advocacy for meritocratic rule while Confucian elitist values undermine participatory democrats' (Sor-hoon Tan and Stephen Angle) ardor for justifications of active democratic participation. A shared difficulty with both groups is that they tend to overuse one aspect of Confucianism while leaving the status of other elements in limbo. The discussion of participatory democracy and meritocracy is followed by the introduction of an eclectic reading that strikes a dynamic balance between elitist and plebeian values in Confucianism, and which points to the wide gamut of realist democracy that combines democratic election with strong leadership.
\end{abstract}

\section{Keywords}

participatory Confucian democracy - Confucian meritocracy - realist Confucian democracy - classic Confucianism - Confucian political theory - political realism

Recent focus on the relationship between Confucianism and democracy has shifted away from examining their mere compatibility to discussing possibilities 
of "Confucian democracy" and "Confucian meritocracy" that build on the intellectual strength of both traditions. What is involved in this burgeoning scholarship in Confucian political theory is as much the clashes of "ought" as clashes of "is." Different normative stances are often undergirded by a basic disagreement on the interpretation of Confucian texts and the Confucian tradition in general. If we conceive of Confucianism as an integral school of thought with tangible conceptual boundaries, then what seems baffling is polarizing tendencies left by the hammer of Confucian democracy and the anvil of Confucian meritocracy insofar as seemingly contradictory implications are drawn from the same tradition. In this light, it seems pertinent to pause before delving into more extensive normative engagement and examine how Confucian these theories are and how they relate to the often-contested contour of the Confucian tradition.

In this article, I turn to the complex and often convoluted relationship between Confucianism and democracy by revisiting textual underpinnings of Confucian democratic and meritocratic theories and, following my textual critiques, discuss what type of Confucian polity follow a balanced reading. In the following section, I justify my question by mapping it onto the conceptual landscape of current theoretical discussion. I then examine why Confucian plebeian and elitist values do not square with the meritocrats' (Daniel A. Bell and Tongdong Bai) advocacy for meritocratic rule and the participatory democrats' (Sor-hoon Tan and Stephen Angle) ardor for justifications of participatory democracy respectively. A shared difficulty with both groups is that they tend to overuse one aspect of Confucianism while leaving the status of other elements in limbo. The discussion of participatory democrats and meritocrats is followed by the introduction of an eclectic approach that strikes a dynamic balance between elitist and plebeian ideas in Confucianism, and which points to a realist democracy that combines democratic election with strong leadership.

\section{$2 \quad$ Problems with the Current Debate}

The status of the current debate can be grasped by attending to two markedly irreconcilable normative stances taken by Confucian participatory democrats and meritocrats. Many Confucian democrats, on the one hand, attempt to bring Confucianism in line with democratic visions by reinterpreting and reconstructing Confucian texts. For them, the relevance of Confucian values today lies in various ways in which they can articulate and justify the democratic 
polity that is participatory and egalitarian. ${ }^{1}$ On the other hand, for Confucian meritocrats, at stake is not so much the idea of cultivating democratic spirit in light of Confucianism as leadership selection and the good governance delivered by competent political leaders. For them, the distinctive contribution of Confucianism lies in revitalizing a society guided by meritocratic leadership as a viable alternative to liberal democracy. ${ }^{2}$

While what drives the two camps apart can, in part, be ascribed to their disparate ethico-political visions, the dichotomies between the two are also structured by disputes over norms of interpretation. Distinctive ways in which theorists conceive of the Confucian intellectual legacy ${ }^{3}$ have a profound impact on bifurcating patterns presented in their normative theorizing. ${ }^{4}$ For Confucian meritocrats, Confucianism is a rich reservoir of elitist ideas that combine public service to the people with morally justified hierarchy. These ideas are sustained by a complex interplay of fair opportunities for education and public office, the division of labor between elite and people, and perfectionist policies aimed at elevating the living standard and moral caliber of ordinary people. ${ }^{5}$ For them, ancient Confucians did not have a clue about "rule by the people." Rather, they put forward a political order that promotes the wise and the worthy "for the people." One contemporary meritocrat even coined the term "political Confucianism" to refer to an authoritarian form of government

1 Roger T. Ames and David L. Hall, The Democracy of the Dead: Dewey, Confucius, and the Hope for Democracy in China (Chicago: Open Court, 1999); Sor-hoon Tan, Confucian Democracy: A Deweyan Reconstruction (Albany: SUNY Press, 2003); Stephen C. Angle, Contemporary Confucian Political Philosophy (London: Polity, 2012); Sungmoon Kim, Democracy After Virtue: Toward Pragmatic Confucian Democracy (Oxford: Oxford University Press, 2018).

2 Tongdong Bai, "A Mencian Version of Limited Democracy," Res Publica 14, no. 1 (2008); Tongdong Bai, Against Political Equality: The Confucian Case (Princeton: Princeton University Press, 2019); Daniel A. Bell, Beyond Liberal Democracy: Political Thinking for an East Asian Context (Princeton: Princeton University Press, 2006); Daniel A. Bell, The China Model: Political Meritocracy and the Limits of Democracy (Princeton: Princeton University Press, 2016).

3 What count as Confucianism and the Confucian tradition/legacy, which are used interchangeably in this article, are fiercely contested. I adopt an interpretive approach that focuses on pre-Qin Confucian thought (from Kongzi to Xunzi) as an intelligible school of thought worthy of philosophical inquiry. A justification of my approach is offered later in this section.

4 This does not mean that the dichotomies cannot be cross-cutting. One may find Confucian values largely non-democratic while adapting them to democratic theory, an example of which is Sungmoon Kim's theory. For Kim's view, see Kim, Democracy After Virtue, Chapters 1 \& 2. My claim is simply that many theorists' disagreement does center around different textual understandings.

5 Bell, Beyond Liberal Democracy, Chapter 6; Bai, Against Political Equality, Chapters 2 \& 3. 
gainsaying the secular legitimacy of popular sovereignty. ${ }^{6}$ From a meritocratic perspective, it is virtually impossible to associate ancient Confucians with popular participation, and staying faithful to the tradition means that we should focus on rule by the worthy.

In marked contrast, underlying various accounts of Confucian democracy is often a candid optimism that Confucian values support, and even call for, democracy understood either as a political institution or as a collective social ethos. Confucian democrats are sanguine about "plebeian ideas" in Confucianism not because democracy is the strongest suit of pre-modern Confucianism - which is surely anachronistic, but because they find profound affinities between democracy and what Joseph Chan calls "Confucian spirit."7 For them, Confucianism, when interpreted properly, requires democracy as the social and political form in which its spirit materializes. ${ }^{8}$ From a democratic perspective, highlighting the democratic potential of Confucianism dovetails with Confucian spirit. Put differently, democracy is not just compatible with Confucianism, but more importantly can be justified in Confucian terms, thereby making a decisive case for "Confucian democracy."

I have gone some length to sketch the morass of the debate that is pulling in strikingly opposite directions. It seems clear by now that a crucial part of the controversy stems from the interpretive questions of what Confucianism has to offer and how far the texts can stretch in terms of their theoretical elasticity, which it is incumbent on Confucian political theorists to address but which many conveniently shortcut. At stake is not simply an issue of compatibility between Confucianism and the proposed polities, but a more acute one of justification, that is, whether and how meritocracy and democracy can be justified on Confucian terms. I will discuss, in this article, four prominent thinkers in the two groups: Daniel A. Bell, Tongdong Bai, Sor-hoon Tan, and Stephen Angle. I argue that each of the groups has a lopsided view of the elite-plebeian nexus, thereby developing normative visions incongruent with some subset of core Confucian values. I also further argue that a balanced reading leads to a wide range of realist democracy that stays independent of participatory and meritocratic polities.

6 Qing Jiang, A Confucian Constitutional Order: How China's Ancient Past Can Shape Its Political Future (Princeton: Princeton University Press, 2013).

7 Joseph Chan, Confucian Perfectionism: A Political Philosophy For Modern Times (Princeton: Princeton University Press, 2013).

8 Tan, Confucian Democracy, Chapters 2 \& 3; Stephen C. Angle, Sagehood: The Contemporary Significance of Neo-Confucian Philosophy (Oxford: Oxford University Press, 2009), Chapters 10 \& 11; Angle, Contemporary Confucian Political Philosophy, Chapter 2. 
If sound, the combination of the two arguments - a negative one against current textual readings and a positive one suggesting a prospect for realist democracy - will chart a new path for envisioning Confucian democracy. To that end, I argue against two species of conventional wisdom. One view pervasive in the current debate is that Confucianism is primarily about hierarchical rule that leaves little room for the agency of the people. The other view, which is popular among Confucian democrats, is that Confucianism, in order to justify democracy, must put itself in a position to support citizens' active involvement in politics. Though my approach remains largely interpretive, the tangible shape of Confucianism's intellectual reach bears on normative theory in ways that affect the leeway and limit that go along with it.

The interpretive task is particularly relevant in two aspects. ${ }^{9}$ First, addressing them can help us better understand different flavors of Confucianism to which various normative theories of democracy and meritocracy subscribe. Insofar as the theorists trace their primary arguments to Confucianism, they owe us an explanation of why we should follow the way they read the texts thereby tethering the Confucian legacy to their specific normative arguments. Similarly, what David Elstein calls "Confucian-inspired democrats" such as Sungmoon Kim also owe us an explanation of why Confucian norms cannot play an active role in structuring the shape of Confucian democracy. ${ }^{10}$ Second, within the Confucian tradition, "a fight over how a text is to be read is a fight over the meaning of the Confucian tradition itself."11 The way Confucian democrats and meritocrats interpret the Confucian texts should be contested rather than assumed given that textual reading bears on the meaning and intellectual intelligibility of Confucianism, which is often put at risk when mutually contradictory messages are sent out as a result of theorists' diverse reading regimens. For Confucian theorists, the battle is especially worth fighting not because they take the texts as an orthodoxy tout court, but because they are acutely aware of both the danger of simply importing fixed and absolute norms from without and the immense value of building a modern polity "best suited

9 My justification of the interpretive approach is also a response to the feasibility concern given that Confucian political theorists' concern is largely about normative issues confronting contemporary societies and presumably less about how texts should be read, one may wonder whether a potential textual mismatch can unleash real challenges to their normative theorizing.

10 David Elstein, "Why Early Confucianism Cannot Generate Democracy," Dao 9, no. 4 (2010). Kim can be seen as belonging to this category insofar as he fully commits himself to values of democracy (both instrumental and intrinsic) while regarding Confucianism as largely tangential to them.

11 Daniel K. Gardner, "Confucian Commentary and Chinese Intellectual History," The Journal of Asian Studies 57, no. 2 (1998): 409. 
to the unique conditions of their communities." ${ }^{12}$ In other words, an exercise of interpretation draws the limits of possibility within which normative claims must lie.

Some critics have already taken up the issue head-on and examined the connection between Confucian texts and Confucian political theory.13 One problem with their approaches is that they tend to confine their focus to Confucian democrats while leaving the meritocrats' interpretive work largely intact as if Confucianism is, by default, meritocracy in precisely the way that certain meritocrats suggest. Another particular difficulty is that they often become too exegetical, meaning that the texts are deciphered in light of their strictly literal meanings rather than enduring values embodied in the texts. Given the predominance of non-democratic rule in Confucian texts, this "toomuch-exegesis" approach is naturally biased against Confucian democracy, which makes the latter a strawman that is easy to defeat while dismissing the democrats' emphasis on Confucian values. My discussion therefore will build on their insights but focus on the force of values presented in the texts, which is largely interpretive. ${ }^{14}$ Overall, another feature of my approach is combining an examination of how the theorists say with what theorists do not say, that is, ways in which proponents of some texts circumvent the uneasy encounter with other texts incongruent with their normative visions.

Before plunging into further textual engagements, two caveats are worth making. One is about the mentioning of Confucianism or the Confucian tradition, whose contours are often in dispute. Confucianism is indeed a complex tradition with diverse ideas and methods emerging in different periods of time, which is part of the reason why theorists often convey divergent messages in justifying their normative claims. As Tan points out, Confucianism is "a complex and continuously changing discourse that has transformed itself and

12 Sor-hoon Tan, "How Can a Chinese Democracy Be Pragmatic?," Transactions of the Charles S. Peirce Society 47, no. 2 (2011): 208.

13 Joseph Chan, "Democracy and Meritocracy: Toward a Confucian Perspective," Journal of Chinese Philosophy 34, no. 2 (2007); Justin Tiwald, "A Right of Rebellion in the Mengzi?," Dao 7, no. 3 (2008); Elstein, "Why Early Confucianism Cannot Generate Democracy"; Loubna El Amine, Classical Confucian Political Thought: A New Interpretation (Princeton: Princeton University Press, 2015).

14 The differences among exegetical, interpretive, and (as will be mentioned later) extrapolative approaches are worth making and they primarily lie in the extent to which a reader stays faithful to the texts. Simply put, while the exegetical work dissects the specific wording of the texts, interpretation identifies values embodied in the texts. Extrapolation goes beyond texts themselves to ask hypothetical questions of what Confucian masters would say should they confront contemporary issues. 
other traditions, and it has, in turn, been transformed by other traditions." ${ }^{15}$ In fact, the thought of Confucianism has been so diverse as to lead Angle to claim "Confucianisms" instead of Confucianism to make sense of "many, even competing, ways in which the legacy of Confucius has been developed over the centuries." ${ }^{16}$ Evidently, the problem has become so acute as to drive all cautious theorists to embark on their discussion with the question of "which Confucianism?"17

Against this backdrop, we should first decide whether to approach Confucianism as a slew of interconnected texts or simply as habits and mores and I lean toward prioritizing the former over the latter. ${ }^{18}$ I go for the former because textual references are more tangible than Confucianism as mere habits and mores. At least there will be an agreement on where disagreement lies when the same body of texts is in view. In terms of texts, I focus on classic Confucian thought that stretches from Kongzi to his disciples including Mengzi and Xunzi. Their differences notwithstanding, "the whole body of canonical texts within a given self-conscious tradition may decisively shape the problematique in terms of which later thinkers confront the world."19 My claim is not that myriad texts bearing the banner of "Confucianism" are fully reconcilable within the original scope of argumentation, but that the canonical texts constitute an indispensable part of the tradition that all self-conscious Confucians cannot comfortably eschew. Also, these texts are also extensively used by the participatory democrats and meritocrats that I examine, which can help to defy the charge that I use idiosyncratic or controversial sources to criticize them. ${ }^{20}$

The second caveat relates to diverse strands of democratic theory that are often too readily glossed over by Confucian democrats and meritocrats alike,

15 Tan, Confucian Democracy, 7.

16 Angle, Contemporary Confucian Political Philosophy, 1.

17 Bai, Against Political Equality, 1.

18 This issue is particularly raised by Kim who argues that culture should come before texts because contemporary East Asia is characterized by Confucian habits and norms, not by the endorsement of ancient texts. There are many difficulties for this cultural reading not least because Confucianism as a philosophy can offer much more than a motley assortment of habits and mores.

19 Benjamin I. Schwartz, The World of Thought in Ancient China (Cambridge: The Belknap Press of Harvard University Press, 1985), 2.

20 Angle's insight owes as much to classic thinkers as to Song-Ming Neo-Confucianism, but he is also subject to my critiques both because of the defining role of classic Confucianism and because the ethico-political nature of my critique does not undermine his Neo-Confucian sources of inspiration whose major contribution lies in metaphysics and personal ethics. 
which is part of the reason why complexities of the Confucian polity are relegated to a dichotomy. For the meritocrats, merit-based selection seems to be the default on which normative discussion is hinged while for many democrats, democracy presupposes citizens' moral agency and active participation in politics. This, however, is a false dichotomy because they tend to downplay the possibility of a middle ground occupied by a range of realist democracy tracing back to Max Weber and Joseph Schumpeter. ${ }^{21}$ The proposal of realist Confucian democracy here does not add up to a comprehensive espousal of a particular regime type, which lies beyond the scope of this paper, but invites ways in which one can think beyond meritocracy and participatory democracy while staying within Confucian conceptual parameters.

\section{Political Meritocracy versus Plebeian Values in Confucianism}

As a self-confessed meritocrat, Bell is particularly vexed with the problems inherent in liberal democratic regimes and seeks to provide stable and longterm solutions that, he believes, can be gleaned from what he calls "political meritocracy."22 Similarly, Bai is concerned with the liberal democratic order of one-person-one-vote but presents the model of what he calls "Confu-China" as a viable Confucian alternative that is universally applicable. ${ }^{23}$ These normative visions are grounded in their shared understanding of the meritocratic contribution of Confucian thought, which binds them as "meritocrats." ${ }^{24}$ Let's first take a coup d'œil of the elitist ideas that meritocrats glean from classic Confucianism, which are comprised of two parts, one referring to the division of labor between elite and people and the other pointing to perfectionist governance stemming from such a socio-political division.

The division of labor argument is often invoked with reference to Mengzi. In ${ }_{3} \mathrm{~A}_{4}$ of the Mengzi, we find him distinguishing between those who "labor with their minds" and those who "labor with physical strength" as a justification of the former's rule over the latter. The passage reads as follows.

21 Max Weber, "The Profession and Vocation of Politics," in Economy and Society: An Outline of Interpretive Sociology (Berkeley: University of California Press, 1978); Joseph A. Schumpeter, Capitalism, Socialism and Democracy (London: Routledge, 2010), Chapters 21 \& 22. for Democracy: Political Meritocracy in Comparative Perspective, ed. Daniel A. Bell and Chenyang Li (Cambridge: Cambridge University Press, 2013), 55-87.

23 Bai, "A Confucian Version of the Hybrid Regime," 65.

24 Bai, Against Political Equality, 82. 
There are affairs of great persons (daren) and there are affairs of petty persons (xiaoren)... Hence, it is said, 'There are those who labor with their minds and there are those who labor with their physical strength. The former govern; the latter are governed. Those who govern are supported by those who are governed.' This is a principle accepted by the whole Empire. ${ }^{25}$

The distinction between daren and xiaoren accords with his view that the vast majority of the people do not have constant livelihood and therefore cannot have constant hearts. ${ }^{26}$ The meritocrats take Mengzi as suggesting that given that there is a socio-political division of labor between ruling a state (which should be trusted to the worthy) and menial work (which is inextricably the focus of ordinary people), ordinary people ought to obey the rule of the meritocratic elite who are both morally and intellectually superior. ${ }^{27}$ While entrusting huge public responsibilities to the elite, the meritocrats also urge the incumbent ruler to cultivate virtues and abilities in exercising self-restraint, extending humane concern and protecting the welfare of the people, which contrasts with perfectionists' exclusive focus on ordinary people's virtues in the West.

For Bai and Bell, elite-led politics leads all the way down to perfectionist governance that is entirely for the people, and there is no impetus in Confucianism to pursue a politics that even approximates rule by the people. Appealing to Kongzi's saying that "the common people can be induced to travel along the way, but they cannot be induced to realize it" 28 and that "those among the common people who do not learn even when vexed with difficulties - they are at the bottom of the heap," ${ }^{29}$ Bell suggests that the ruler's responsibility is in "bringing accord to their peers," which is a task with which an exemplary person should concern herself. ${ }^{30}$ Inspired by Mengzi, Bai argues that the ruler's concern is with not only nurturing the people's physical wellbeing, which includes "a full belly and warm clothes,"31 but also imparting virtues and taking

25 Mengzi 3 A4. All translations of the Analects and the Mengzi, with minor modifications, are from Dim Cheuk Lau, Confucius: The Analects (London: Penguin, 200o); Mencius (London: Penguin, 1970). References to the Xunzi are from Xianqian Wang 王先謙, Xunzi jijie 荀子集解 [Collected Commentaries of Xunzi], (Beijing: Zhonghua Shuju, 1988).

26 Mengzi $1 \mathrm{~A}_{7} ; \mathrm{B}_{3}$.

27 Bai, Against Political Equality, 45 .

28 Analects 8.9.

29 Ibid. 16.9.

$30 \quad$ Ibid. 14.42.

31 Mengzi $1 \mathrm{~A}_{3}, 1 \mathrm{~A}_{5}, 1 \mathrm{~A}_{7}, 2 \mathrm{~A}_{5}, \mathrm{~A}_{3}$. 
care of their moral wellbeing. ${ }^{32}$ Consequently, the top priority of the meritocrats is the "involvement of the morally and intellectually superior in the decision-making process." ${ }^{33}$

In light of the meritocrats' textual engagement, the increasingly orthodox vox populi is that the "Confucian character of recent proposal(s) of Confucian meritocracy can hardly be questioned." ${ }^{44}$ Although there is virtually no reference to mechanisms resembling the imperial examination or representative quota system advocated by Bai and Bell, classic Confucians did emphasize the meritocratic quality (xian) of rulership, ${ }^{35}$ which is delivered by adopting meritbased selection methods. The priorities given to the notion of merit proceed to justify a wide array of meritocratic political structures including merit-based selection and a top leadership unaccountable to democratic citizens, thereby making for Confucian justifications of meritocracy. Bell favors a system where meritocratic selections apply to the top level and democracy is only exercised at local, communal settings while Bai endorses a more complex hybrid regime where a debilitated democratic chamber at the top is blended with Bell's topdown model. ${ }^{36}$ The limited scope of popular participation in Bai and Bell is based on the view that "a Mencian would think the right of political participation in decision-making processes should be based on intellectual, moral, and political competence."37

The issue of normative plausibility aside, there are certainly some areas in which one can take exception to meritocratic textual readings. For instance, we may object to the equation of merit with Confucian virtues, petty persons with the common people, as well as the intensity of coerciveness involved in meritocracy with that in classic Confucianism, and advise modification of meritocratic theory along the Confucian line. ${ }^{38}$ But is the political landscape depicted by the meritocrats all we can tell of classic Confucianism save some moderate tinkering with it? A deep immersion into the texts speaks otherwise. One of

32 Ibid. $1 \mathrm{~A}_{3}, 1 \mathrm{~A}_{7}, 3 \mathrm{~A}_{3}, 6 \mathrm{~B} 8,7 \mathrm{~A} 14,7 \mathrm{~A} 2 \mathrm{O}$.

33 Bai, Against Political Equality, 47.

34 Kim, Democracy After Virtue, 27.

35 See Mengzi 1 $\mathrm{A}_{2},{ }_{1} \mathrm{~B}_{7}, 2 \mathrm{~A} 4,3 \mathrm{~A}_{3}, 4 \mathrm{~A}_{7},{ }_{7} \mathrm{~B}_{12},{ }_{7} \mathrm{~B}_{24}$; Xunzi, "Zhongni," “Wangzhi."

36 Bell previously favored democratic and meritocratic chambers at the national level but later backtracked and came to defend democracy only in the local community. For their recent views, see Bell, The China Model, Chapter 4; Bai, Against Political Equality, Chapter 3 .

37 Ibid., 70.

38 Fred Dallmayr et al., "Beyond Liberal Democracy: A Debate on Democracy and Confucian Meritocracy," Philosophy East and West 59, no. 4 (2009); Yong Huang, "Bell's Model of Meritocracy for China: Two Confucian Amendments," Philosophy East and West 69, no. 2 (2019). 
the most formidable challenges to the meritocratic reading of Confucian political legitimacy perhaps comes from the Wanzhang chapters in the Mengzi where, contrary to the view that Mengzi only offers rule for the people but not by them, ${ }^{39}$ a case for proto-democratic reading is on the horizon. I shall henceforth illustrate my challenge to the meritocratic reading of Confucianism with reference to these chapters. ${ }^{40}$

In $5 \mathrm{~A} 5$ and $5 \mathrm{~A} 6$ of the Mengzi, his disciple Wanzhang asks whether it is true that Sage-King Yao simply gave power to Shun, another Sage-King following Yao's demise. Says Mengzi, "the King cannot give the empire to another" but only "recommend" his thought to Heaven. "Yao put Shun in charge of ritual sacrifices, and the various spirits were pleased with him. This was Heaven accepting him. He put Shun in charge of affairs, and the affairs were wellordered, and the people were at ease with him. This was the people accepting him." ${ }^{11} \mathrm{~A}$ similar account is given of Shun's abdication to Yu, the last Sage-King in the abdication story, and the succession of Yu by his son Qi.

While Mengzi is usually taken as favoring rule for rather than by the people, the supreme verdict that legitimated the legendary transfer of political power recounted in these chapters seems to be entirely up to the expression of the people in conjunction with the requirement that no tragic mischance happen, which is a fairly formal threshold at Mengzi's time. The sheer notion of the people accepting a ruler paves the way for mechanisms through which rulership becomes subject to, and more importantly legitimated by, popular approval. The significance of this egalitarian twist - which I call "plebeian values" should not be underestimated. The reason that Mengzi's popular approval is

39 Elstein, "Why Early Confucianism Cannot Generate Democracy," 436.

40 While some other anecdotes may read as referring to political legitimacy, they are often ambiguous as to whether they speak of governing well or legitimately, the two being conceptually different. In contrast, Mengzi's account of abdication directly illustrates who is giving power to whom and on what basis. Also, I focus on Mengzi because his account best displays Confucian plebeian values while cases can be a bit murky in Kongzi and not so plebeian in Xunzi. Kongzi's ambiguities mean that his account is flexible enough to befittingly join Mengzi in delivering on the "Way of Kongzi and Mengzi" (kongmeng zhidao). Xunzi is more complicated, first, because his discussion of power transfer in defiance of the Mengzian account in the "Zhenglun" chapter is not readily applicable to the contemporary world. Xunzi's two sources of sagely power transfer, sagely charisma and continuation of Confucian rituals, are both lost and cannot make sense in modern ages. Second, Xunzi is also often deemed a transitional figure to Chinese Legalism advocating the skillful use of force, so the lack of plebeian values in Xunzi just shows the start of a trend toward undervaluing Confucian plebeian spirit. 
plebeian in character rather than actively participatory lies in the fact that the people only approve of, not directly participate in, political governance.

If we grant this plebeian view of Confucian legitimacy, it may potentially destabilize one of the fundamental pillars of Confucian meritocracy, namely that the elite directly claim a right to rule by virtue of having politically relevant merit, given that the meritocratic leader does not need to be held democratically accountable to be legitimate. There, however, seems a long way to go between the idea of the people being at ease with the appointment of a ruler and democratic mechanisms of one-person-one-vote. Partly because of Mengzi's linguistic ambiguities and economical use of words, commentarial disputes tend to center around whether popular demand plays a decisive role, the relative agency of the people compared to that of feudal lords and of Heaven, and the weight of political stability. ${ }^{42}$

One effective strategy of confronting these interpretive difficulties, I suggest, is distinguishing between the basic parameter on which the threshold of political legitimacy is hinged and exegetical details secondary to it. Only when Mengzi's priorities are settled first can we come to terms with the whole legitimation process. On the one hand, the recurrent notions of Heaven and the people as well as their close intertwinement in classic Confucianism strongly suggest popular approval as crucial to the validation of political legitimacy. ${ }^{43}$ On the other hand, popular behavior is qualified by internal expectations that the people are reasonably demanding. An even mediocre ruler would always be endorsed by the people as long as he adheres to Confucian rituals and protocols, which is why the Confucian masters relentlessly exhorted the incumbent ruler, however emaciated or prodigal he is, ${ }^{44}$ to practice self-cultivation and roll out benevolent policies. ${ }^{45}$ Indeed, nowhere in the classic texts can we find an indication that the people would subvert a sufficiently good ruler.

If qualifications are put in place ensuring that popular demand do not go astray, one may wonder whether it is a) popular approval itself or b) the hypothetical consensus on the distinctive character of Confucian rulership that the

42 See Chenyang Li, “Confucian Value and Democratic Value," Journal of Value Inquiry 31, no. 2 (1997); Tiwald, “A Right of Rebellion in the Mengzi?”; Elstein, “Why Early Confucianism Cannot Generate Democracy"; Sungmoon Kim, "Confucian Constitutionalism: Mencius and Xunzi on Virtue, Ritual, and Royal Transmission," The Review of Politics 73, no. 3 (2011); El Amine, Classical Confucian Political Thought, Chapter 1.

43 One important notion is all-under-Heaven (tianxia) which combines Heaven with human beings. See, e.g. Analects 12.1, 12.22, 14.6.

44 In the sense of saying regardless of whether the ruler has an emaciated moral sense or a well-developed one, he should practice self-cultivation.

45 Analects 2.19, 2.20, 12.19, 13.4. 13.6, 13.13. Mengzi 1A.3, 1A.5, 1A.6, 1A.7, 1B.4, 4A.9, 4B.3, 7A.23, 7B.37. Xunzi, "Wangba," “Jundao." 
people would reasonably come to endorse anyway that is ultimately decisive. The meritocrats favor the second line of reading. Bai interprets Mengzi's view, not as the people's actual voice being decisive, but as reducing the transcendental role of Heaven to a more secular and normative one of "service to the people" in that what matters is good governance to the people's "satisfaction." 46 For Bai, popular demand under the name of Heaven in Mengzi serves the same function as natural rights do in the name of God in John Locke.

I suggest, however, that there is sufficient, compelling reason along the first line of reading. First, the people may approve of not only sage-kings but also satisfactorily competent or even mediocre rulers. If we conceive of Confucian legitimacy as befitting some kind of normative (contra actual) consensus and if such a consensus upholds the supreme Way (dao) as the ultimate dictum, then it would be difficult to explain why a mediocre ruler should be preferred to a moral exemplar especially when we take into account the decisive weight reserved for the ruler in Confucianism. ${ }^{47}$ This is not to deny the weight of merit in Confucian thought - indeed, it is plausible to infer that merit indirectly connects to the popular mood by improving the quality and performance of governance. Merit, however, does not sanction its own authority but needs to be vindicated by such measures as are necessary for the establishment of authority. Maximizing merit is not a categorical threshold and the weight of the merit is subject to the people's gaze. It is in this sense that Mengzi urges the ruler to "win their (the people's) hearts" and "collect for them what they like, and not to lay on them what they dislike,"48 on which the whole meaning of rulership depends. ${ }^{49}$

46 Bai, Against Political Equality, 38-39.

47 One may further query whether we can envision a hypothetical consensus on stability that comes atop benevolent politics. As a response, first, existing texts fall short of showing that concern over stability preempts normative visions in Confucianism. Second, even if stability figures in the overarching ethical-political vision, it is all but un-Confucian to interpret the lack of popular support as a sign of contributing to stability. On the contrary, Confucians' volatile attitudes toward hegemons' rule underlines the importance of popular support.

48 Mengzi 4 A9.

49 Given that Mengzi did not talk much about the role of the people in approving or disapproving satisfactory-but-non-ideal rulers, the anonymous reviewer raised an important hypothetical question of how Mengzi would choose between Yao's feckless son and a decent but not sagely ruler who garners popular support. In light of my discussion, Mengzi's preference is probably for the latter because, first, popular approval does not disappear when power is transferred along hereditary lines - an abysmal ruler can still be thrown out. Second, the idea of "winning the people's heart" means that popular expression always matters and hereditary rulers are legitimate because Mengzi is confident that they 
Second, in contrast to the narrative of hypothetical consensus where popular approval is designated as nominal rather than actual, the idea that popular approval is necessarily constitutive of political legitimacy entertains another advantage. For it makes sense of Confucian political legitimacy without undermining normative visions that intuitively stay on top of legitimacy thresholds that may be met under not so ideal conditions of hegemonic rulership $(b a) .50$ Speaking of political legitimacy in a different context, Bernard Williams makes a meaningful distinction between what qualifies a state as minimally legitimate and the ideas of justice that sit atop the requirement of state legitimacy. ${ }^{51}$ Back in the Mengzian case, we may claim that popular demand, by being necessarily constitutive of, though not sufficient for, the Way, serves to legitimate political rule without diluting the higher ideals of benevolent or sagely politics.

Laying out the basic conceptual parameters not only enables us to accommodate the rest of factors that prima facie obstructs a proto-democratic reading but also puts us in a better position to grapple with the difficulties with meritocratic reading. The idea of stability can be factored in evaluating the whole panorama of political legitimacy in the Mengzi but it should be understood as internally connected to, rather than contending with, the people's collective endorsement of rulership - a rulership without popular support cannot be stable. The tutelary role of feudal lords in relaying the expression of the people in the public sphere as well as the quasi-theistic language of Heaven can be appreciated not necessarily as barriers to the egalitarian reading but as flexible arrangements that endow popular approval with a tangible shape and which, without too much conceptual difficulty, can be translated into a democratic system of popular approval where the people publicly affirm the legitimacy of the ruler.

One challenge to my interpretation merits particular attention. One may liken Mengzian popular approval to popular consent, the latter of which characterizes the modern value of popular sovereignty. Consent, as the challenge goes, is only the source of legitimacy and is not tethered to any specific form of government including democracy. One may further argue that, popular approval, whether being consensual or not, may give rise to non-democratic regimes..$^{52}$ This challenge, however, makes sense only if popular approval in

would have popular support as long as they behave satisfactorily, not because they are legitimate regardless of what ordinary people think.

Xunzi particularly speaks highly of hegemons, who were short of true kinghood but capable of delivering on stability and prosperity. See Xunzi, "Wangba."

51 Bernard Williams, In the Beginning Was the Deed: Realism and Moralism in Political Argument (Princeton: Princeton University Press, 2005).

$5^{2}$ Chan, "Democracy and Meritocracy," 186-187. 
Mengzi is read in a way that closely mirrors popular sovereignty. Indeed, there is nothing in the doctrine of popular sovereignty that requires the assignment of power to a particular set of people - be it a king or a group of democratic representatives. Popular sovereignty largely emerged in early modern England and America where different narratives were contrived in ways that built political legitimacy on a holistic, consensual, and hypothetical shape of the fictional people in order to facilitate modern state-building. ${ }^{53}$ In contrast, Mengzi's emphasis, as my discussion shows, is on constant, actual expression on the part of ordinary people, not on the need to conjecture the hypothetical consent of the people. If we closely attend to Mengzi's views that actual approval from the people matters in terms of political legitimacy, and that their approval should be constantly renewed insofar as the very idea of approval prevents them being muted following one single act of approval, ${ }^{54}$ we may find his plebian values much closer to electoral democracy than popular sovereignty is.

Thus conceived, the plebeian view of legitimate rulership poses a formidable challenge to meritocratic thinking as a continuum of Confucian thought insofar as political meritocracy tends to violate the basic plebeian structure of Confucian thought. Although Bai's and Bell's political meritocracy often involves some limited democratic mechanisms, they, by being relegated to marginal status, are neither decisive nor justified in Confucian terms. This does not mean, however, that Confucians should embrace active democratic participation. Strictly speaking, what Mengzi shows us is not "rule by the people" but "rule approved by the people" with the crucial distinction lying in whether the people participate in the day-to-day management of ruling, and as we shall see in the section of this paper "Toward Realist Confucian Democracy," this has crucial implications for Confucian democracy. ${ }^{55}$ The reason for the meritocrats' hasty endorsement of merit as a self-authoring threshold, however, is not unfathomable as they tend to conflate the meritocratic criteria for the conscience of the Confucian intellectual as super-citizens, with the legitimacy threshold of rulership, which has the idea of popular approval integral to it. ${ }^{56}$

53 Edmund S. Morgan, Inventing the People: The Rise of Popular Sovereignty in England and America (New York: WW Norton \& Company, 1989).

54 For Mengzi, popular approval cannot simply be a once-and-for-all deal because the popular mood, which is the source of legitimacy, constantly changes and can be won and lost (Mengzi 4A9).

55 For democracy as government approved by the people, see Schumpeter, Capitalism, Socialism and Democracy, 246.

56 See Sungmoon Kim, "To Become a Confucian Democratic Citizen: Against Meritocratic Elitism," British Journal of Political Science 43, no. 3 (2013): 591. The insight here is that Confucian meritocracy is exemplified by intellectuals claiming to embody the conscience of society, not by rulers of high office. 
If my discussion so far is sound, it shows that it is possible and necessary to combine meritocratic with plebeian values in order to stay faithful to Confucian heritage. Forsaking the latter is tantamount to creating an inevitable rupture between the normative claims they make and the tradition on which they intentionally piggyback. Before exploring the possibility of marriage between elitist and plebeian ideas in detail, we need to attend to participatory Confucians' interpretation of the Confucian texts, which pushes normative arguments in an opposite direction but, as I shall argue, succumbs to the same kind of misinterpretation as their meritocratic counterparts.

\section{Participatory Democracy versus Elitist Values in Confucianism}

Compared to the meritocrats, participatory Confucian democrats may bear more burdens of proof in their Confucian justifications of democracy given that the case for a proto-democratic reading of Confucianism is not as straightforward - though unequivocally present, as I argued in the previous section - as the case for political meritocracy. This difficulty is evidenced by a long uneasy relationship between Confucianism and democracy that troubled the Chinese intellectual community from the May Fourth debate to a torrent of crossfire between New Confucians and liberals in Taiwan and Hong Kong after the communist takeover of China, and further to contemporary disputes.

Not surprisingly, participatory democrats, Tan and Angle, did not attempt to directly read off democratic proposals from the Confucian texts but took a more sophisticated strategy of expanding the notions of Confucianism and democracy in order to attain a secure conceptual space where Confucian democracy can blossom. Tan takes what she calls "an anti-essentialist hermeneutical stance" that treats Confucianism as "the meaningful continuity of a tradition of scholarship and social practice wherein discourses about ideals and norms relate to actual practice in dynamic tension." ${ }^{.57}$ Angle takes inspiration from Song-Ming Neo-Confucianism and the New Confucianism of Zongsan Mou, which are even more flexible in terms of textual interpretation as long as the central thread of the orthodoxy (daotong) is adhered to. ${ }^{58}$ Both Tan and Angle also have expansive notions of democracy with Tan's view heavily informed

57 Tan, "Confucianism and Democracy," in Confucianism in Context: Classic Philosophy and Contemporary Issues, East Asia and Beyond, Wonsuk Chang and Leah Kalmanson, eds., (Albany: SUNY Press, 2010), 105.

$5^{8}$ For the centrality of daotong to Confucianism, see John Makeham, New Confucianism: A Critical Examination (New York: Springer, 2003), Chapters 1 \& 2. 
by the Deweyan pragmatic understanding of democracy as collective social inquiry in pursuit of a good community and Angle's view "guided by our emotionally tinged perception of ... interconnections." ${ }^{\prime 5}$ Their double immersion into renewed understandings of Confucianism and democracy brings about new perspectives in ways that are not seen in political meritocracy.

Tan and Angle, however, also demonstrate meaningful varieties in justifying democracy in Confucian terms. Tan's idea heavily relies on natural affinities she finds between classic Confucianism and John Dewey's pragmatism in terms of the individual as a social being, moral wellbeing as role ethics and the community as a harmonious process of joint collective inquiry. ${ }^{60}$ Although her approach may, at some juncture, leave one confused as to whether she is trying to uncover the democratic potential of Confucianism or simply altering Confucian thinking in ways that bring it up to pragmatic standards, she is explicit that the anti-democratic reading of Confucianism "turns its back on" other crucial parts of the Confucian tradition, an approach that dovetails with the method of interpretive inquiry that I set out. ${ }^{61}$ Angle, on the other hand, is also clear that he sees Confucianism as offering insights about fundamental human virtues not confined to one particular tradition. What he dubs as "rooted global philosophy" 62 points to the importance of working within the Confucian tradition and drawing on sources from within to shed light on salient political issues.

There are, in general, two strands, rather than a single thread as some tend to argue, ${ }^{63}$ present in each of Tan's and Angle's Confucian justifications of democracy. On Tan's part, her first line of thought is that Confucian virtue cultivation justifies democratic participation by way of first connecting Confucian learning to personal self-growth, and further Confucian rituals to the bonds of the harmonious community that involves participating in a community where members "establish others in seeking to establish themselves and promote others in seeking to get there themselves." 64 Insofar as Confucianism advocates "making an earnest commitment to the love of learning," 65 and this kind of learning to be humane can only be possible in collective social inquiry aimed

\footnotetext{
59 Angle, Contemporary Confucian Political Philosophy, 48.

6o Tan, Confucian Democracy, Chapters 2 \& 3.

61 Tan, "Confucian Democracy as Pragmatic Experiment: Uniting Love of Learning and Love of Antiquity," Asian Philosophy 17, no. 2 (2007): 151.

62 Angle, Contemporary Confucian Political Philosophy, 9.

63 Kim understands Tan and Angle as exclusively focusing on virtue cultivation. Kim, Democracy After Virtue, 29.

64 Analects 6.30.

65 Ibid., 8.13.
} 
at the development of human potentialities, Tan concludes that a Deweyan democracy is a natural corollary of Confucian dual emphases on learning as moral growth and ritual as uniting the harmonious community.

The second strand in Tan is a development of Mengzi's "rule for the people" thesis based on the Wanzhang chapters, which we have already looked into with some detail. While Tan believes that Heaven in the Mengzi and other texts is not reducible to the people's actual voice but part and parcel of a normative notion - which aligns her more with the meritocrats' than with my reading, she does not arrive at the same conclusion as the meritocrats do. Her creative move hinges on a Deweyan insight that "the only effective method for achieving government for the people (is) government by the people."66 The idea is that if Confucians are committed to serving the interests of the people, they should also accept that the only effective way in which these interests can be served consists in citizens' figuring out problems and solutions for themselves, which translates to democratic governance that is both social and political. ${ }^{67}$

Similarly, there exist two strands in Angle's Confucian justification of democracy. The first strand is characterized by the "self-restriction" thesis that he readily takes over, with some modifications, ${ }^{68}$ from Zongsan Mou, a leading twentieth century New Confucian who again was heavily influenced by Kant. The idea of self-restriction involves the claims that 1 ) Confucians are committed to seeking full virtue; 2) full virtue must be realized in the political world; 3) the public realization of full virtue requires political institutions that restrict the ways in which Confucian moral judgement is applied to the political realm; 4) and, therefore, the achievement of virtue requires self-restriction. ${ }^{69}$ Despite the heavy dose of virtue, at the heart of self-restriction is the distinction between Confucian ethics and politics from the vantage point of the Confucian intellectual instead of virtue per se, suggesting a deontic requirement that a Confucian not apply her own ethical standards to the general public at her whim but always exercise self-restraint by respecting the political institution of democracy.

His second line of argument primarily pertains to a reconstruction of the people-Heaven nexus in the Mengzi by reading a creative interpretation of the Neo-Confucian concept "Coherence" (li) into Mengzian Heaven. As in Tan's second argument, Angle also engages with the Wanzhang chapters, which reveals

\footnotetext{
66 Tan, “How Can a Chinese Democracy Be Pragmatic?," 211.

67 Tan, Confucian Democracy, 145.

68 Angle's primary departure from Mou is in severing the idea of self-restriction from Mou's controversial metaphysical assumptions.

69 Angle, Contemporary Confucian Political Philosophy, 29.
} 
the "people's contentedness with their well-being" as the "actual conduit of the state's legitimacy."70 However, Angle reads Mengzi as showing a tension between the people as a passive sign of good governance and everyone's equal moral potential. For the people to be active rather than passive, Angle turns to innovatively expanding on the Neo-Confucian notion of Coherence. To the extent that 1) Coherence requires one to cultivate virtues in appreciating the harmonious interconnectedness of human beings, and 2) that these myriad interrelationships can only be grasped in a democracy where all human beings "recognize and respond to ethically salient aspects of life,"71 Confucianism (or a progressive version of Neo-Confucianism) calls for the adoption of democracy. The self-restriction and Coherence theses are not unrelated as Angle deploys the insight from self-restriction as an argument against the view that those excelling at appreciating Coherence should have more say than others in politics. Nevertheless, they are not dependent on one another for consistency and intelligibility.

The second strand in Angle shares a strikingly similar structure with the first in Tan insofar as they both directly invoke the value of personal self-cultivation to justify democracy. The rationales for Tan's second, and Angle's first, lines of thought are rather different, which I discuss first. From a textual perspective, one may be struck by how extrapolative their arguments are, which do not fall back on any direct textual references. For Tan's transition from rule for the people to rule by the people to make sense, one needs to subscribe to many Deweyan assumptions about human psychology and collective behavior informed by neo-Hegelianism, which are not self-evident in Confucian context. ${ }^{72}$ Absent these assumptions, one may query whether Deweyan democracy is the only way of reconciling rule for and by the people in Confucianism especially if democracy is not understood in pragmatic terms, and further why some tinkering with political meritocracy with an introduction of democratic accountability cannot also effectively deliver rule for the people while preserving Confucian elitist ideas. In this light, justifying democracy in this way is contingent on non-Confucian ideas unintelligible to non-Deweyan Confucians.

The same kind of difficulties also apply to Angle in that the effort to pry apart Confucian ethics and politics, recapitulated as "self-restriction," is not textually evident either even with sufficient leeway for interpretation. ${ }^{73}$ Angle

$70 \quad$ Ibid., 39 .

71 Ibid., 5 o.

72 For Dewey's assumptions about human psychology, see Andrew Backe, "John Dewey and Early Chicago Functionalism," History of Psychology 4, no. 4 (2001).

73 Qing Jiang 蔣慶, Zhengzhi Ruxue: dangdai Ruxue dezhuan hua, tezheng yu fazhan 政治 儒學: 當代儒學的轉化、特征與發展 [Political Confucianism: The Transformation, 
is aware that "Mou does not read the idea of self-restriction back into the tradition" and the point is rather that the spirit of self-restriction resonates with that of early Confucian thinkers. ${ }^{74}$ My aim here is not to fight the idea of self-restriction, which may fully make sense if we experiment extrapolative contra interpretative methods of studying Confucian thought. Self-restriction, however, is nowhere to be found within the interpretive pedigree of Confucian texts, which gives us sufficient reason to cast doubt on its Confucian character. The relevance of self-restriction to Confucianism is bound to be attenuated if textual interpretation alone short of further speculation is capable of grounding democracy.

If we return to Tan's first and Angle' second lines of thinking, which coincide in grounding democracy in Confucian virtue cultivation, further questions, beside the issue of logical inconsistency, ${ }^{75}$ may arise, questions that cast doubt on the Confucian character of their accounts. First, one may wonder how distinctively Confucian the virtues thus cultivated are given the notable gap between pragmatic and progressive ideals of active participation and the Confucian ideal of promoting the worthy and the able. Democratic participation may engender virtues and vices that do not overlap with Confucian virtues. ${ }^{76}$ Even when political participation is at stake, it is reserved for the Confucian gentry (shi) who, through relentless self-cultivation, extend the insights gained in family life to their public responsibilities. Even being a Confucian does not imply a wholehearted interest in politics - says Kongzi, "do not concern yourself with matters of government unless they are the responsibility of your office."77 If participatory democrats and early Confucians have distinct ideas of political participation in mind, it is difficult to pin down how Confucian the virtues are that are nourished through large-scale democratic participation. Second, a question also arises as to whether there are alternative ways in which personal moral growth can be attained or best attained through non-political social engagements. Third and more serious still, widespread democratic participation may turn out to be detrimental to core Confucian virtues including deference,

Character and Development of Contemporary Confucianism], (Beijing: Joint Publishing, 2003), 57-95.

74 Angle, Contemporary Confucian Political Philosophy, 32.

75 The immediate conceptual hurdle, though not about textual interpretation, is making sense of the leap from cultivating a capacity for virtue to the deontological right of political participation. Given the perfectionist and situationally fluctuating nature of Confucian ethics, it seems theoretically precarious to ground democratic participation in Confucian understandings of virtue, ceteris paribus.

76 Joseph Chan, “'Self-Restriction' and the Confucian Case for Democracy," Philosophy East and West 64, no. 3 (2014); Kim, Democracy After Virtue, 29. 
modesty and loyalty. ${ }^{78}$ Angle does propose a way forward through "deference without oppression," ${ }^{79}$ but a further question that results is how much of deference is still there when active citizens believe that they are entitled to being the ultimate judge of everything concerning the community.

In the end, the gravity of the problems with Tan and Angle comes down to what they omit to say, that is, their glossing over an aretaic asymmetry in Confucianism between the moral growth of the elite and that of ordinary people, which is given short shrift as a result of their hasty pursuit of participatory ideas at the expense of Confucian ones. As recently pointed out by El Amine, "the qualities expected of the common people are not the cardinal Confucian virtues of ren, rightness $(y i)$, and wisdom $(z h i)$, that Confucius expects of himself and his disciples." ${ }^{\circ 0}$ One indication of this asymmetry in terms of virtue cultivation is the lopsided relationship between ruler and people as mirroring that between daren and xiaoren. In classic Confucianism, the ruler, as long as he behaves, is morally superior to the people to such an extent that the former is often depicted as in a position to lead while the latter, by blindly following customs and treasuring the prolongation of one's own life, are morally despicable. ${ }^{81}$ In this light, Confucian virtue cultivation, which is far from egalitarian and politically participatory, cannot support the idea of citizens cultivating virtues through democratic participation.

The participatory democrats' impetus to do away with this asymmetry and extend the requirement of personal growth from the elite to the general populace, though comprehensible as a radical overhaul of Confucian thought, should be treated with utmost caution. For the dynamic, albeit lopsided, relationship between elite and ordinary people is not tangential but integral to the tenor of Confucian thought, which is taken seriously by the meritocrats but problematically assumed away by the participatory democrats.

At the heart of Confucian ethico-political thinking is the idea of enlightened rulership for which the transformative quality of the ruler is the most important factor though other ingredients of rulership such as ritual and music also have integral roles to play. Says Kongzi, "the rule of virtue can be compared to the Pole Star which commands the homage of the multitude of stars without leaving its place," and also, "to govern is to correct. If you set an example

78 For instance, in the Analects 2.20, Kongzi says that the way to make the people deferent and loyal is by rendering public the ruler's solemn presence and piety to parents, not by anything resembling the people's political participation.

79 Angle, Contemporary Confucian Political Philosophy, 111.

80 El Amine, Classical Confucian Political Thought, 32.

81 Analects 12.19. Mengzi 6A14, 6A15. Xunzi, "Ruxiao," "Renlun." 
by being correct, who would dare to remain incorrect?" 82 The classic texts are full of the Confucian masters' confidence that if a good ruler is in charge, the society will resume order and stability and the people will become voluntarily obedient. On the contrary, if a corrupt ruler resumes office, the malevolent character of rulership itself is sufficient to bring about disorder and moral decay. In short, the intimate relationship between who is in charge and the quality of order stays at the center of Confucian political theorizing.

One of the crucial ramifications of enlightened rulership is the sociopolitical division of labor emphasized by the meritocrats. If we briefly recall the meritocrats' division of labor argument, different intellectual and moral abilities displayed by elite and people justify the former's status as the governor and the latter's as the governed. After all, the meritocrats are justified in saying that "only ethical and intellectual elites have a vocation to lead society ... as the bulk of persons are not thought capable of exercising such initiative." ${ }^{83}$ Benign rulership along with the division of labor between elite and common people is not aimed at perpetuating the intellectual and moral gap left by the aretaic asymmetry identified above, ${ }^{84}$ which is a gross misreading of classic Confucianism, but a realist reckoning, as meritocrats agree ${ }^{85}$ that it is virtually impossible to increase the moral and intellectual capabilities of all to such an extent as makes them equally qualified to make collective decisions for the common good, and further that this necessary societal fact warrants a proper division of labor that makes the wise and the capable rule. This realist twist of Confucian ethical-political thought runs deep down to the core of the tradition, which, as we shall see, has profound implications for the kind of polity that we can build on the Confucian soil.

I argued in the previous sections that neither political meritocrats' nor participatory democrats' reading of Confucianism provides a fairly balanced picture of the Confucian legacy and how it informs the polity firmly built on its

\footnotetext{
82 Analects 2.1, 12.17.

83 Bell, Beyond Liberal Democracy, 153 .

84 While not everyone is required or expected to cultivate cardinal virtues, there is nevertheless an internal connection between Confucian ethics and politics, which El Amine fails to appreciate. For El Amine's view, see her Classical Confucian Political Thought, 30-7. For a critique of her view, see Eirik Lang Harris, "Relating the Political to the Ethical: Thoughts on Early Confucian Political Theory," Dao 18, no. 2 (2019).

85 Bai, Against Political Equality, 45-6.
} 
values. The meritocrats, Bai and Bell, tend to gloss over the plebeian strands in Confucian thought while the participatory democrats, Tan and Angle, make little room for elitist values to flourish. The subsequent question, then, is how we can turn on reconciling elitist and plebeian ideas in anticipation of a polity that does not cherry-pick Confucian legacies?

The very possibility of this reconciliation lies, I argue, in reconfiguring what we too readily assume as democratic and starting to perceive democratic elections not so much as a participatory and egalitarian exercise but as a complex manifestation of both plebeian and elitist values. Election is not treated as a venue for active participation of democratic citizens but rather as an instrument of "democratic elitism" that facilitates the elite's public acclamation through popular approval. The association of election not with actively participatory but aristocratic values had a long history before the advent of the American and French Revolutions. In ancient Athens where the idea of democracy originally blossomed, democracy was seen as lot, which implies a rotational idea of "ruling and being ruled in turn." ${ }^{86}$ In contrast, the emergence of representative government by the dawn of the modern age was not a return of ancient democracy but a new way of combining elitist and plebeian concerns. For Bernard Manin, the elite characters of election manifest themselves in at least four ways: in the unequal treatment of candidates by voters according to socially recognized meritocratic values, in the superior distinction of candidates required by a situation of choice, in the cognitive advantage by visual and charismatic salience, and finally in the cost of information that only the elite can afford to bear and maintain on a constant basis. ${ }^{87}$

What results is a renewed understanding of democracy as what political theorists often call "realist democracy" that performs the dual functions of the elite's promotion and public acclamation, which features in Weber's plebiscitarian democracy, ${ }^{88}$ and of democratic control, which is a government "approved by the people" but not directly governed and managed by them. ${ }^{89}$ The key to the concept of realist democracy in Confucian context is the reconciliation of plebeian and elitist values, that is, the simultaneous presence of

86 Josiah Ober, Mass and Elite in Democratic Athens: Rhetoric, Ideology, and the Power of the People (Princeton: Princeton University Press, 2009), 7-8.

87 Bernard Manin, The Principles of Representative Government (Cambridge: Cambridge University Press, 1997), 134-48.

88 Weber, Economy and Society, 266-71.

89 For realist democracy, see Richard A. Posner, Law, Pragmatism, and Democracy (Cambridge: Harvard University Press, 2005); Adam Przeworski, Democracy and the Limits of Self-Government (Cambridge: Cambridge University Press, 2010); Ian Shapiro, The State of Democratic Theory (Princeton: Princeton University Press, 2009). 
popular approval and elite selection through the "aristocratic" measure of election. Democracy of this kind is realist not in the sense of prioritizing the political realm as precluding external (moral) values from playing a major role, ${ }^{90}$ inasmuch as this politicized interpretation of realism is alien to the Confucian tradition where self-cultivation, familial care and politics are ceaselessly intertwined. Rather, it is realist in the sense of taking seriously the factual and psychological constraints in the ruler-ruled relationship and further internalizing these constraints as constitutive of Confucian ethico-political visions. ${ }^{91}$

Realist democracy here should be understood not as a particular regime type but as an umbrella term that subsumes many variations: from a weak democracy that only endows the people with the power of accepting or refusing a leader, to Schumpeterian competitive democracy where "individuals acquire the power to decide by means of a competitive struggle for the people's vote." 92 In light of my interpretive approach, I am not advocating any specific variant of realist democracy given that an argument with such precision will require further extrapolative work and normative discussion that go beyond the scope of this article. My claim is rather that the umbrella term of realist democracy, which occupies a conceptual ground robust enough to distinguish itself from political meritocracy and participatory democracy, best captures Confucian plebeian and elitist values, thereby breathing genuine intelligibility to the notion of "Confucian democracy."

Against this backdrop, we may single out Joseph Chan's account of Confucian democracy as particularly relevant because of the way he weaves together the elite selection mechanism of election and the idea of democratic control without soliciting citizens' substantial political participation. Chan offers two ways in which electoral democracy can be justified: under non-ideal conditions, a robust voting system instrumentally holds politicians accountable by deterring them from trampling upon the common good and under ideal conditions, election is also expressive of the sense of bond and mutual trust between ruler and electorate. ${ }^{93}$ Chan's justifications of democracy, by virtue of combining

$90 \quad$ For the "politics first" approach, see Bonnie Honig, Political Theory and the Displacement of Politics (New York: Cornell University Press, 2016); Chantal Mouffe, The Return of the Political (London: Verso, 2005). However, not all realists subscribe to this approach. For instance, Bernard Williams's political realism does not champion politics as such, but only prescribes morality tailored to the political context.

To map onto Galston's taxonomy, Confucian realism denounces utopianism and simplistic moral psychology without granting the "autonomy of politics." See William Galston, "Realism in Political Theory," European Journal of Political Theory 9, no. 4 (2010): 387-40o.

92 Schumpeter, Capitalism, Socialism and Democracy, 269.

93 Chan, Confucian Perfectionism, Chapters 3 \& 4. 
popular approval with elite selection in a unified notion of democracy, stands for a variant of realist democracy. ${ }^{94}$ Nevertheless, his hermeneutics of ideal and non-ideal are misleading inasmuch as Confucian political thought is nonideal or realist all the way down - even Sage-Kings cannot assume a title to top office but go through the legitimation process of popular approval.

We may wonder why early Confucians, especially Mengzi, believed in the people's ability to approve or disapprove of a ruler if they lack virtues and abilities necessary for governing themselves. We can at best speculate by putting ourselves into the shoes of Mengzi. The subtlety of Mengzian reasoning consists in 1) the moderate nature of the people's capabilities as robust enough to tell what they like and dislike but short of abilities for self-governance, and 2) the sufficiency of the basic ability to tell where their welfare is in screening out the incompetent ruler. One does not need to understand all areas of professional expertise to tell who is competent from who is not because all that matters from a plebeian perspective is that the people can feel that their lives are getting better, not how the elite render that possible. Although this chimera of optimism and pessimism about the people is open to challenge from democratic viewpoints, it at least elucidates why classic Confucianism accommodates seemingly contradictory but remarkably consistent views in one stream of thought.

The brief discussion above is not conclusive but only suggests a general direction of the future development of Confucian democracy. Nevertheless, it provides a unique anchor by virtue of which we can further examine the difficulties with the meritocrats and participatory democrats. While the meritocrats do not deny the mechanism of minimal democratic participation, it is neither upheld for Confucian reasons - which is the plebeian value of Confucianism - nor endowed with decisive power. Participatory democrats, on the other hand, unduly push the elitist input of Confucianism to the margin, thereby cutting short what it means to be Confucian. Losing sight of the whole picture of Confucianism and what the opposite side gets to say in a constructive dialogue is the thin end of the wedge that triggers further problems for their normative discussion.

A factor contributing to their rather compartmentalizing views of Confucianism is the idea of active participation that they hold as essential to

94 We still see a tendency in Chan to water down the idea of election as elite selection when he claims that his model is not necessarily aristocratic but accommodates the egalitarian idea of likeness - the idea that leaders are chosen not because of their merit but according to how they resemble the electorate's opinion, which I see as an unnecessary and even counterproductive move in light of the Confucian plebeian and elite values. 
democracy despite substantially different concepts of democracy to which the two groups subscribe. Both Tan's pragmatic democracy and Angle's progressive democracy require democratic citizens' active participation not only in voting but in the value-laden process of collective virtue cultivation. Because they mold the meanings of democracy in this particular way, they have no option but to bend Confucian values in ways that render them supportive of active participation to the detriment of elitist ideas. While Bai's and Bell's shared understanding of democracy as the liberal democratic regime pertains to the realist category, they still see democratic election as quintessentially antithetical to the elite's meritocratic rule. The unwitting upshot is that merit is pitted against, rather than reconciled with, electoral democracy.

To be fair to the meritocrats and participatory democrats, it is not difficult to see where their rather uncompromising views of democracy and thus of the possibilities of reconciling Confucianism with democracy come from. Tan's affection for Deweyan pragmatism leads her to take elitism as "the enemy of democracy" that should be bracketed off altogether in democratic discussion. ${ }^{95}$ Angle, a progressive follower of Mou, shares the latter's disdain for "subordination" that resulted in the romanticized, egalitarian "coordination" of virtuecaring citizens. ${ }^{96}$ The problem for Tan and Angle is that the abhorrence of non-democratic elitism combined with an inner drive to a more egalitarian form of Confucian politics blinds them to the ways in which elitist ideas can be sustained in a plebeian structure of realist democracy. On the other hand, the meritocrats' penchant for uncovering the full drive of Confucian heritage, which they take as embodied in meritocratic values, mixed with a particular uneasiness with liberal democracy the essential core of which is democratic election, prompts Bell and Bai to hold fast to non-democratic selection methods. This tendency, in turn, comes to hobble the plebeian side of Confucianism.

From a historical perspective, what is undeniable is the burden of proof that Confucian theorists inevitably bear in confronting the accompaniment of Confucianism with autocratic rule in the pre-modern history of East Asia, which inevitably blurred the plebeian, not elitist, current of Confucianism. The intimate relationship between ruling power and Confucians was not established until the reign of Emperor Wu of Han (141-87 BC), which inherited Qin's (221-206 вС) official scholar system that subsumed intellectuals as the ruler's servants, though its root can be further traced back to the School of Jixia

95 Sor-hoon Tan, "Beyond Elitism: A Community Ideal for a Modern East Asia," Philosophy East and West 59, no. 4 (2009): 545 .

96 Zongsan Mou, Zheng dao yu zhi dao 政道與治道 [The Way of Governing and the Way of Politics], (Taipei: Student Publishing 2010). 
in the state of Qi during the Warring State period (475-221 BC) ${ }^{97}$ The process of subjugating intellectuals to power began with the Qin dynasty when Li Si, Qin's powerful prime minster, accused intellectuals of "hearkening back to the ancient only to damage the present." 98 Under the supervision of Emperor Wu, Han Confucians exemplified by Zhongshu Dong systematically restructured the remnants of Confucian classics that survived the burning and burying of Qin and finally enshrined Confucianism as the only legitimate transmitter of the Way. Weiming Tu, a contemporary New Confucian, speaks of what transpired in Han as a situation where the "Confucianism that eventually emerged as the predominant court philosophy was no longer the teachings of Confucius and Mencius." ${ }^{\text {99 }}$ As a result, the aggrandizing tendency of elitist values that gradually evolved from Han's practice of turning Confucianism from "orthopraxy" to "orthodoxy,"100 is treated as a fait accompli by friends and foes of Confucianism. The exclusive spotlight on Confucian elitism then carried mixed verdicts for contemporary theorists - while the meritocrats turned the table and cast a fresh light on elitist values, many democrats, petrified of the dark side of elitism and determined to uncover the original spirit of Confucianism, went over the top in aligning themselves with the egalitarian drive of Confucianism.

I shall make a prognosis of three possible reservations about realist Confucian democracy before concluding my discussion. Given the promising prospect of realist democracy being grounded in Confucianism, one may first query if the two intellectual schools just converge and their differences collapse. The brief answer is that Confucian democracy, when properly understood, is a subspecies of realist democracy. To the extent that being faithful to the Confucian tradition requires taking both plebeian and elitist values seriously, realist democracy is the polity of a kind that results from a balanced reading of Confucianism. In contrast, its prototypical alternatives including political

97 Yuri Pines, The Everlasting Empire: The Political Culture of Ancient China and Its Imperial Legacy (Princeton: Princeton University Press, 2012), 76-103.

98 "The Basic Annals of the First Emperor of Qin," in The Records of the Grand Historian.

99 Wei-ming Tu, "The Structure and Function of the Confucian Intellectual in Ancient China," in The Origins and Diversity of Axial Age Civilizations, ed. Shmuel. N. Eisenstadt (Albany: SunY Press, 1986), 367.

100 Michael Nylan, "Boundaries of the Body and Body Politics in Early Confucian Thought," in Confucian Political Ethics, ed. Daniel A. Bell (Princeton: Princeton University Press, 2010), 85 . 
meritocracy and participatory democracy tend to cherry-pick some part of the tradition while unduly diminishing the others. The implication is that any configuration of the contemporary Confucian polity should take seriously the framework of realist democracy though not all of the latter is, or indeed should necessarily be, Confucian.

A subsequent question is, grant that realist democracy comes to take on Confucian attributes following a Confucian justification of democracy, how realist democracy displays and maintains its distinctively Confucian character. This question can be approached in two ways, from the perspectives of elitist and plebeian values. From an elitist perspective, if we take 1) election as an elite-generating process, and 2) political participation as necessary for the Confucian elite's self-cultivation, then election can be seen as both a training ground for the Confucian elite and a seedbed of elite virtues where the elite can strive for their own moral development. From a plebeian perspective, the function of democracy as popular control is expressive of both ideas of popular approval and of the minimal, albeit decisive, role assigned to ordinary people. The Confucian character of realist democracy can be further strengthened if we put it in a social context comprised of Confucian habits and mores, and further introduce screening measures for evaluating candidacy thresholds aligned with cardinal Confucian virtues.

The last concern may turn the issue around by asking how realist Confucian democracy can gain a competitive edge and what normative import it carries from a democratic perspective. Some may be worried that short of normative justifications, the value of interpretative work remains uncertain. Indeed, interpretive work cannot provide direct normative guidance, but first, it can help to disambiguate different flavors of Confucianism that figure in increasingly diverse accounts of Confucian democracy and meritocracy. When the vivacity of Confucian values is attenuated to such an extent that the integrity of Confucian thought is put at risk as in the cases of political meritocracy and participatory democracy, we may find better names for them, say, "Confucian-inspired" democracy and meritocracy. The second aspect of interpretive-normative connectivity lies in the normative significance of interpreting Confucian thought insofar as a fight over the meaning and scope of the texts is a normative battle concerning the intelligibility of Confucianism itself. Treating Confucianism both as an integral school of thought and as an unfailing way of life requires us to appreciate the kind of politics that is to grow in Confucian soil rather than compartmentalize its values to make way for the triumph of modernity.

The interpretive work is only the start of a colossal task of coping with the issue of Confucian modernity. Looking beyond the dichotomy between participatory democracy and political meritocracy may give us a unique edge in 
thinking through the way forward for Confucian democracy today. Taking realist Confucian democracy seriously can enable us to make sense of the true rhythm of cultural dynamism engendered by the challenges and opportunities of modernity in Confucian societies. The realist twist can also help Confucian theorists transition from ideal to non-ideal modes of theorizing, that is, from the pursuit of ideal participation or impeccable, non-democratic selection methods to a focus on how the existing electoral system, which is within our grasp here and now, can be reformed and improved in light of overarching Confucian values. Initiatives of realist Confucianism may just be in the offing, and this article would like to invite readers to look on this realist turn with as much vigor as patience. ${ }^{101}$

\section{Biography}

Yutang Jin is a PhD candidate in political theory at the Department of Politics and International Relations, Oxford University. His research interest lies at the intersection of comparative political theory and Confucian philosophy focusing on the Confucian justifications of democracy. He is the author of the article "Confucian Justifications of Democracy: A Critique of Joseph Chan's Democratic Theory," which is published in Philosophy East and West.

101 I would like to thank Professor Eirik Harris, an anonymous reviewer and Jinxue Chen for their detailed comments on the earlier drafts of this article. This article also benefited immensely from vigorous conversations with Professor Stuart White, Professor Stephen Angle, and Professor Nicholas Bunnin, and I am always in their debt for their mentorship. 